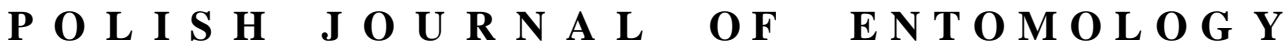

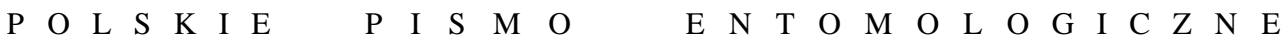

VOL. 84: 201-210

Lublin

30 September 2015

DOI: $10.1515 /$ pjen-2015-0017

\section{Screen traps as an efficient method in faunal research on fungus-feeding thrips (Tubulifera: Phlaeothripidae)}

\author{
HALINA KUCHARCZYK ${ }^{1}$, MAREK KUCHARCZYK ${ }^{2}$, LUKASZ WYROZUMSKI ${ }^{1}$ \\ ${ }^{1}$ Department of Zoology, Maria Curie-Skłodowska University, Akademicka 19, 20-033 Lublin, \\ Poland, e-mail: halina.kucharczyk@umcs.lublin.pl,wyrak.w@gmail.com \\ ${ }^{2}$ Department of Nature Protection, Maria Curie-Skłodowska University, Akademicka 19, \\ 20-033 Lublin, Poland, e-mail: marek.kucharczyk@umcs.lublin.pl
}

\begin{abstract}
Studies on fungus-feeding thrips were carried out in two national parks ranked as biosphere reserves: the Białowieża National Park (north-east Poland) and the Bieszczady National Park (south-east Poland). IBL-2 screen traps were used as the main method in the forest communities. Traps were deployed in managed forests and the strict reserve in the Bialowieża NP, and along two trails in the lower forest belt up to its upper border with mountain meadows in the Bieszczady NP. Using IBL-2 traps revealed the presence of ten mycophagous species in the Białowieża NP and six in the Bieszczady NP. In the former Hoplothrips carpathicus, H. fungi, $H$. unicolor and $H$. polysticti, and in the latter $H$. carpathicus and Maderothrips longisetis were recorded for the first time in Poland.
\end{abstract}

KEY WORDS: mycophagous thrips, passive traps, Białowieża National Park, Bieszczady National Park.

\section{INTRODUCTION}

Different methods for collecting insects are used in accordance with the type of habitat studied. In open areas, the entomological sweep net is the most efficient method, which allows one to collect a relatively large number of species. In forest communities where the undergrowth is rather poor (e.g. Norway spruce forest) or develops seasonally (e.g. hornbeam and beech forests in early spring), this method is insufficient and additional ones need to be used. Several types of passive traps are used in studies of species diversity, e.g. 
coloured Moericke traps, Malaise traps, screen traps, photoeclectors and pitfall traps. The first three types are attractive to insects because they contrast with the surroundings; they detect mainly winged forms (LEWIS 1973). The positive or negative photo- or geotropism exhibited by insects is made use of in the soil or tree photoeclectors placed on tree trunks (ZUR STRASSEN 1994, DUBOVSKÝ et al. 2010, MASAROVIČ et al. 2014). With pitfall traps one can investigate insects - mostly apterous forms - actively moving on the ground or in the leaf litter.

Studies of the species diversity and biology of fungivorous and bark-dwelling thrips are very difficult to carry out because of the concealed lifestyle and wide dispersal of their populations; locally, however, they can be very numerous (KoBRo \& SolHeIM 2002). They live on decaying wood, feeding on the hyphae or spores of fungi (MOUND 2002). Their occurrence depends on the presence of old trees in various stages of decay on the forest floor. This kind of habitat is found more often in natural or semi-natural forests than in managed ones, from which fallen branches and logs are removed. Minimal human intervention maintains a large diversity of tree age, including those in various stages of decay. Such unchanged habitats occur mainly in reserves or national parks.

The IBL-2 screen trap used in the present research was constructed at the Forest Research Institute in Białowieża and, among other methods, was used for monitoring research in strictly protected areas of the Białowieża Primeval Forest. In addition, it was used during studies of the migration intensity of the spruce bark beetle (Ips typographus (LINNAEUS, 1758)) - the most serious pest of trees in both protected and managed forests (GUTOWSKI \& KRZYSZTOFIAK 2005). In addition to the beetles, 35 species from the order Thysanoptera were caught, among them fungi-feeding species, during this study. This inspired us to use this type of trap in research on Thysanoptera species diversity in the Bieszczady National Park. To date no systematic studies of thrips diversity in this region have been carried out.

This paper presents the results of investigations on the species diversity of fungivorous thrips in two national parks in Poland - the Białowieża National Park and the Bieszczady National Park. In the discussion we compare the effectiveness of IBL-2 screen traps with other passive traps used in faunal studies of thrips in woodland habitats.

\section{STUDY AREA AND METHODS}

The study was carried out in two national parks - the Białowieża NP (NE Poland) and in the Bieszczady NP (SE Poland) (Fig. 1). The former was established in 1932 and is the last surviving primeval deciduous and mixed forest in the European lowlands, whereas the latter was established in 1973 and is a part of the Eastern Carpathians. Both of them have 
the rank of biosphere reserves: the Białowieża Forest Biosphere Reserve and the East Carpathians Biosphere Reserve, respectively. In both regions IBL-2 screen traps were deployed along two transects. In the Białowieża Primeval Forest one straddled the national border between the strict reserve on the Belarussian side and managed forests on the Polish side, while the other followed the "Browska Way", which runs along the border of a strict reserve in the Białowieża NP. Hornbeam (Tilio-Carpinetum) and mixed forests (QuercoPiceetum) were dominant in both plots. In the Bieszczady NP traps were deployed in beech forests (Dentario glandulosae-Fagetum) and Norway spruce forests (Abieti-Piceetum montanum) in the lower woodland belt. Eight traps were hung along the first trail, from the village of Wołosate (804 m amsl) to Mt. Tarnica. (1346 m amsl) (SW slope), and ten traps along the second trail leading from Zatwarnica $(680 \mathrm{~m}$ amsl) to Orłowicz Pass $(1073 \mathrm{~m}$ amsl) (NE slope).

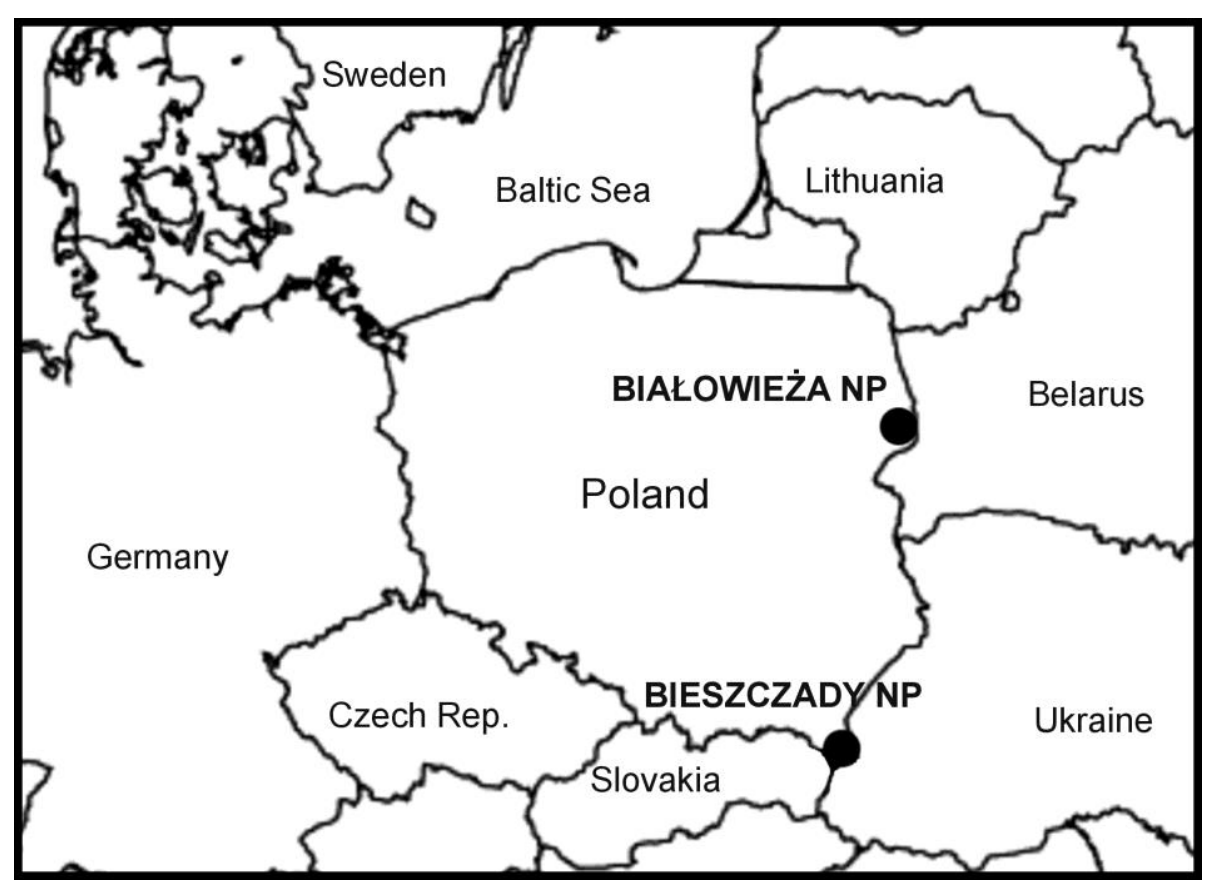

Fig. 1. Location of the study areas. 


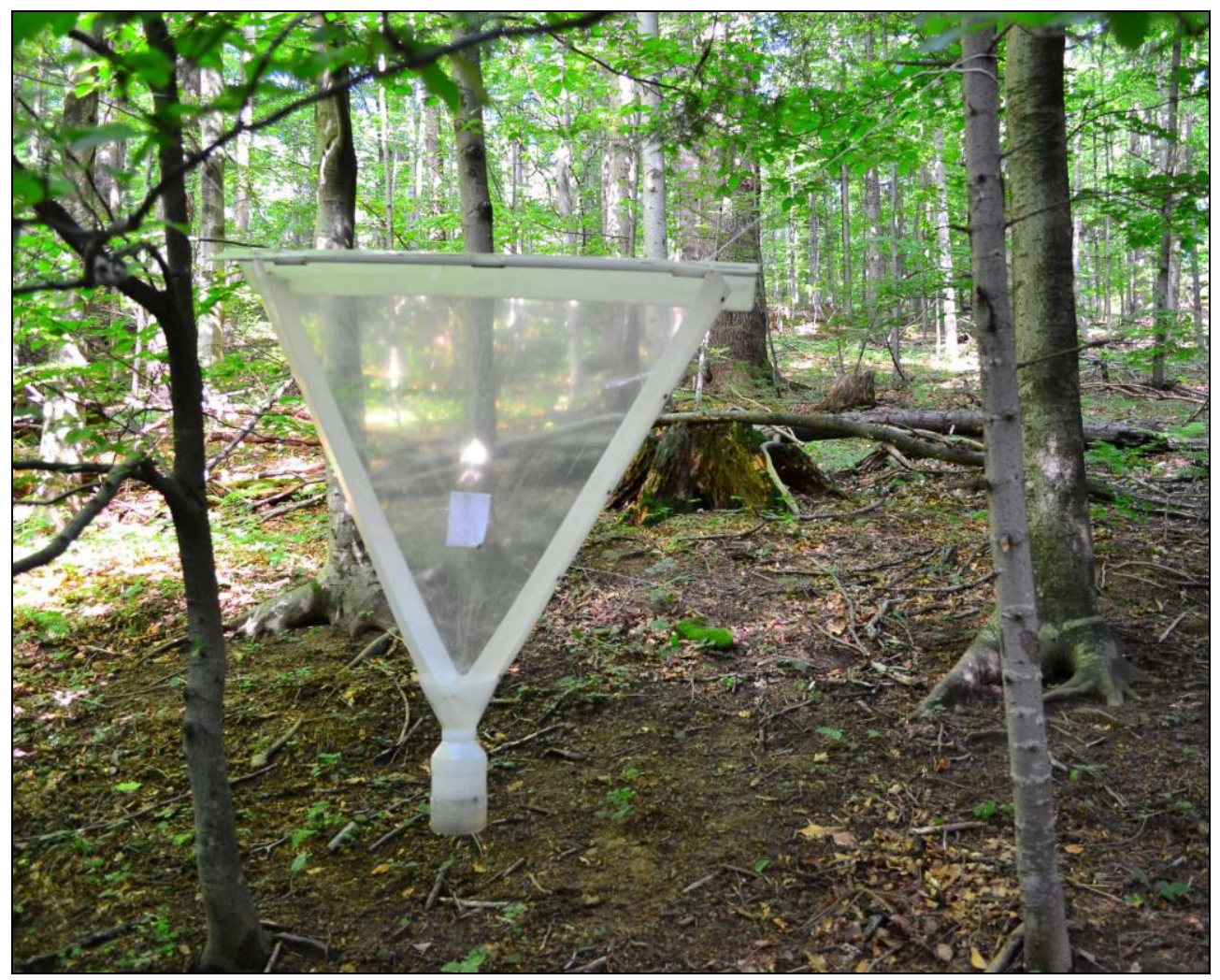

Fig. 1. IBL-2 screen trap in the Bieszczady National Park.

An IBL-2 trap consists of a triangular screen made from translucent white foil (length of side $=90 \mathrm{~cm}$; area $=\mathrm{ca} 0.4 \mathrm{~m}^{2}$ ) and a polythene funnel affixed to a 1 litre bottle filled with an aqueous solution of ethylene glycol as preservative. The upper side of the inverted triangle is covered by a small roof (Fig. 2). No attractants were used in these traps. Traps were hung about a metre above the ground between the trunks of the tree species predominating in the sampling plots and, depending on the weather, they were emptied every 10-14 days from May to October. In the Białowieża NP the insects were taken from the Forestry Research Institute's collection - they had been collected between 1999 and 2001. In the Bieszczady NP materials were collected in the second half of 2012 and in 2013 by the present authors (KUCHARCZYK \& WYROZUMSKI 2015).

After selection from the catch, all specimens were preserved in $70 \%$ ethyl alcohol and then mounted in Berlese fluid or Canada balsam (MOUND \& KIBBY 1998); they were identified according to the key by SCHLIEPHAKE \& KLIMT (1979). Species of the Hoplothrips AMYOT \& SERVILLE 1843 genus were identified according to KOBRO 
\& RAFOSS (2006). All the specimens collected are deposited at the Department of Zoology, Maria Curie-Skłodowska University, Lublin, Poland.

\section{RESULTS}

During the study period in the Białowieża NP 35 thrips species were caught in the screen traps: $21(60 \%)$ were dendrophilous, and ten of these in turn were fungus-feeding species. Four species of the genus Hoplothrips - H. carpathicus PELIKÁN, 1961, H. fungi (ZETTERSTEDT, 1828), H. unicolor (VUILLET, 1914) and H. polysticti (MORISON, 1949) are new to the Polish fauna - and Holothrips schaubergeri (PRIESNER, 1920) is new to the Białowieża Primeval Forest. Hoplothrips pedicularius HALIDAY, 1836 and H. carpathicus were the most numerously and frequently caught on both transects. The other species, apart from $H$. schaubergeri, were recorded singly.

In the Bieszczady NP 20 thrips species were selected from screen traps; 13 (65\%) were dendrophilous and six of these were fungivorous. H. pedicularius and $H$. carpathicus were caught the most often. Maderothrips longisetis (BAGNALL, 1910) is a species new to the Polish fauna: on both transects it was caught in traps deployed in beech forests with many fallen trees. Hoplothrips corticis (DE GEER, 1773) was noted in different forest communities, at both the lowest and the highest altitudes along both transects, which may suggest its large environmental tolerance.

Table 1. Checklist of thrips species (with their food preferences) collected in IBL-2 traps in the Białowieża and Bieszczady National Parks, I and II - number of transect, $\mathrm{D}$ - dendrophilous species, $\mathrm{Fl}$ - flower feeder, $\mathrm{Fu}$ - fungus feeder, $\mathrm{G}$ - grass feeder, $\mathrm{L}$ - leaf feeder, $\mathrm{P}$ - predator.

\begin{tabular}{|c|c|c|c|c|c|}
\hline \multirow[t]{2}{*}{ Thrips species } & \multicolumn{2}{|c|}{ Białowieża } & \multicolumn{2}{|c|}{ Bieszczady } & \multirow{2}{*}{$\begin{array}{c}\text { Food } \\
\text { preferences }\end{array}$} \\
\hline & I & II & $\mathbf{I}$ & II & \\
\hline Aeolothrips intermedius BAGNALL, 1934 & $\bullet$ & $\bullet$ & & & $\mathrm{P}$ \\
\hline Aeolothrips melaleucus HALIDAY,1852 & $\bullet$ & $\bullet$ & & & $\mathrm{D}, \mathrm{P}$ \\
\hline Aeolothrips versicolor UZEL, 1895 & & & & $\bullet$ & $\mathrm{D}, \mathrm{P}$ \\
\hline Aeolothrips vittatus HALIDAY, 1836 & & $\bullet$ & & & $\mathrm{D}, \mathrm{P}$ \\
\hline Chirothrips hamatus TRYBOM, 1895 & & $\bullet$ & & & $\mathrm{G}$ \\
\hline Chirothrips manicatus HALIDAY, 1836 & & $\bullet$ & $\bullet$ & & $\mathrm{G}$ \\
\hline Chirothrips pallidicornis PRIESNER, 1925 & $\bullet$ & & & & $\mathrm{G}$ \\
\hline Dendrothrips degeeri UZEL, 1895 & & & $\bullet$ & & $\mathrm{D}, \mathrm{L}$ \\
\hline Frankliniella intonsa (TRYBOM, 1895) & & $\bullet$ & & & $\mathrm{Fl}$ \\
\hline Frankliniella tenuicornis (UZEL, 1895) & & $\bullet$ & & & $\mathrm{G}$ \\
\hline Limothrips denticornis HALIDAY, 1836 & $\bullet$ & $\bullet$ & & & $\mathrm{G}$ \\
\hline Mycterothrips consociatus (TARGIONI-TOZZETTI, 1886) & $\bullet$ & $\bullet$ & $\bullet$ & & $\mathrm{D}, \mathrm{L}$ \\
\hline Mycterothrips latus (BAGNALL, 1912) & & & $\bullet$ & & $\mathrm{D}, \mathrm{L}$ \\
\hline Mycterothrips salicis (O.M. REUTER, 1879) & $\bullet$ & $\bullet$ & $\bullet$ & $\bullet$ & $\mathrm{D}, \mathrm{L}$ \\
\hline
\end{tabular}


Table 1. Continued.

\begin{tabular}{|c|c|c|c|c|c|}
\hline \multirow[t]{2}{*}{ Thrips species } & \multicolumn{2}{|c|}{ Białowieża } & \multicolumn{2}{|c|}{ Bieszczady } & \multirow{2}{*}{$\begin{array}{c}\text { Food } \\
\text { preferences }\end{array}$} \\
\hline & $\mathbf{I}$ & II & $\mathbf{I}$ & II & \\
\hline Odontothrips phaleratus (HALIDAY, 1836) & & & $\bullet$ & & $\mathrm{Fl}$ \\
\hline Oxythrips ajugae UzEL, 1895 & $\bullet$ & $\bullet$ & & & $\mathrm{D}, \mathrm{Fl} \& \mathrm{~L}$ \\
\hline Oxythrips bicolor (O.M REUTTER, 1879) & $\bullet$ & $\bullet$ & & & $\mathrm{D}, \mathrm{Fl} \& \mathrm{~L}$ \\
\hline Sericothrips bicornis (KARNY,1910) & & $\bullet$ & & & $\mathrm{Fl}$ \\
\hline Stenothrips graminum UZEL, 1895 & & & & $\bullet$ & $\mathrm{G}$ \\
\hline Taeniothrips inconsequens UZEL, 1895 & & $\bullet$ & & & $\mathrm{D}, \mathrm{Fl} \& \mathrm{~L}$ \\
\hline Taeniothrips picipes (ZETTERSTEDT, 1828) & $\bullet$ & & $\bullet$ & & $\mathrm{Fl}$ \\
\hline Thrips atratus HALIDAY, 1836 & & $\bullet$ & & & $\mathrm{Fl}$ \\
\hline Thrips calcaratus UZEL, 1895 & $\bullet$ & & & & $\mathrm{D}, \mathrm{L}$ \\
\hline Thrips flavus SCHRANK, 1776 & & & $\bullet$ & & $\mathrm{Fl}$ \\
\hline Thrips fuscipennis HALIDAY, 1836 & & & & $\bullet$ & $\mathrm{Fl}$ \\
\hline Thrips major UZEL, 1895 & & $\bullet$ & & & $\mathrm{Fl}$ \\
\hline Thrips minutissimus LINNAEUS, 1758 & $\bullet$ & $\bullet$ & & & $\mathrm{D}, \mathrm{Fl} \& \mathrm{~L}$ \\
\hline Thrips physapus LINNAEUS, 1758 & & $\bullet$ & & & $\mathrm{Fl}$ \\
\hline Thrips pini (UZEL, 1895) & $\bullet$ & $\bullet$ & & $\bullet$ & $\mathrm{D}, \mathrm{L}$ \\
\hline Thrips simplex (MORISON, 1930) & $\bullet$ & & & & $\mathrm{Fl} \& \mathrm{~L}$ \\
\hline Haplothrips aculeatus (FABRICIUS, 1803) & $\bullet$ & $\bullet$ & $\bullet$ & & $\mathrm{G}$ \\
\hline Haplothrips subtilissimus (HALIDAY, 1852) & $\bullet$ & & & & $\mathrm{D}, \mathrm{P}, \mathrm{L}$ \\
\hline Holothrips schaubergeri (PRIESNER, 1920) & $\bullet$ & $\bullet$ & & & $\mathrm{D}, \mathrm{Fu}$ \\
\hline Hoplothrips carpathicus PELIKÁN, 1961 & $\bullet$ & $\bullet$ & $\bullet$ & $\bullet$ & $\mathrm{D}, \mathrm{Fu}$ \\
\hline Hoplothrips corticis (DE GEER, 1773) & & $\bullet$ & $\bullet$ & $\bullet$ & $\mathrm{D}, \mathrm{Fu}$ \\
\hline Hoplothrips fungi (ZETTERSTEDT 1828) & $\bullet$ & & & & $\mathrm{D}, \mathrm{Fu}$ \\
\hline Hoplothrips pedicularius (HALIDAY 1836) & $\bullet$ & $\bullet$ & $\bullet$ & $\bullet$ & $\mathrm{D}, \mathrm{Fu}$ \\
\hline Hoplothrips polysticti (MORISON 1949) & & $\bullet$ & & & $\mathrm{D}, \mathrm{Fu}$ \\
\hline Hoplothrips unicolor (VUILLET 1914) & $\bullet$ & & & & $\mathrm{D}, \mathrm{Fu}$ \\
\hline Liothrips setinodis (O.M. REUTER, 1880) & & & & $\bullet$ & $\mathrm{D}, \mathrm{L}$ \\
\hline Maderothrips longisetis (BAGNALL, 1910) & & & $\bullet$ & $\bullet$ & $\mathrm{D}, \mathrm{Fu}$ \\
\hline Phlaeothrips coriaceus HALIDAY, 1836 & $\bullet$ & & $\bullet$ & $\bullet$ & $\mathrm{D}, \mathrm{Fu}$ \\
\hline Phlaeothrips denticauda PRIESNER, 1914 & $\bullet$ & & & & $\mathrm{D}, \mathrm{Fu}$ \\
\hline Xylaplothrips fuliginosus SCHILLE, 1911 & & $\bullet$ & $\bullet$ & & $\mathrm{D}, \mathrm{P}, \mathrm{Fu}$ \\
\hline No. of species: & 22 & 26 & 15 & 11 & - \\
\hline No. of fungus-feeding species: & 7 & 6 & 6 & 5 & - \\
\hline
\end{tabular}

All the mycophagous species collected were from the Phlaeothripinae subfamily. There were no clear differences between the number of fungivorous species on the transects either in the Białowieża NP or in the Bieszczady Mts. Five species were common to both regions, five were caught only in the former and one only in the latter region (Table 1). The greatest number of species was recorded on the plot in the strict reserve in the Białowieża NP. From one to three species were caught in all traps located along transect I in the Bieszczady NP, but there were no fungivorous thrips in four of ten traps on transect II. However, the largest number of fungus-feeding species (four) was found in a trap situated in a spruce forest with a large proportion of artificial plantings of larch (Larix decidua MILLER, 1768). 


\section{DISCUSSION}

To date 34 fungivorous thrips species are known to the Polish fauna: six represent the genera Bolothrips PrIESNER, 1926, Cryptothrips UzEL, 1895, Megathrips TARGIONITOZZETTI, 1881 and Megalothrips UZEL, 1895 of the Idolothripinae subfamily, while the remainder come from the Phlaeothripinae subfamily (KUCHARCZYK 2007, VIERBERGEN 2013 and unpublished data). Because of the concealed lifestyle and wide dispersal of their populations, fungus-feeding thrips are difficult to study. In Poland they were collected singly, mainly in forest habitats (KUCHARCZYK 1994, 1999, 2004, KUCHARCZYK \& KUCHARCZYK 2011, KUCHARCZYK \& WYROZUMSKI 2015). An entomological sweep net was the usual method in faunal research, but while this method allows one to collect large numbers of both specimens and species inhabiting the forest undergrowth, it is insufficient for collecting species that live on dead wood (LEWIS 1973). In the latter case different types of passive traps are more effective. Moericke water traps and screen traps were used during monitoring studies of the invertebrates of the Białowieża Primeval Forest in 1989-99. With the former method seven fungivorous species were collected, of which Hoplandrothrips bidens (BAGNAlL, 1910), Hoplandrothrips williamsianus PRIESNER, 1923 and Phlaeothrips annulipes O.M. REUTER, 1880 were not found in the present study. Similarly, Acantothrips nodicornis (O.M. REUTER, 1880) and Hoplothrips ulmi (FABRICIUS, 1781), caught in screen traps, were not noted later (KUCHARCZYK 2004). Between 1999 and 2001 GUTOWSKI \& KRZYSZTOFIAK (2005) carried out research on saproxylic beetles in the Białowieża forests using IBL-2 screen traps. This method proved to be effective for collecting fungivorous thrips, which constituted of about $28 \%$ (ten species) of all recorded thrips species. The data on new species to the Polish fauna added in the present paper and those published earlier raise the number of fungus-feeding thrips species in the Białowieża Primeval Forest to 15. A similar proportion - 30\% (six species) consisted of fungivorous species caught in IBL-2 traps during the present studies in the Bieszczady NP; except for $M$. longisetis, they were the same as in the Białowieża NP. With the additional data on $M$. longisetis and $H$. carpathicus in the Bieszczady Mts., the number of fungivorous species recorded in the Polish Carpathians increased to 12 (KUCHARCZYK \& STANISŁAWEK 2010, SIERKA et al. 2008).

Passive traps have been also used by other researchers in studies of thrips in forest environments. White water traps suspended at different heights were used by JENSER (1993), who carried out studies on the species composition in an oak forest near Eger in the Bükk Mountains (Hungary). As a result he collected 40 species, eight (20\%) of which were mycophagous. Only H. corticis, Phlaeothrips coriaceus HALIDAY, 1836 and P. denticauda PRIESNER, 1914 were the same as in our studies (JENSER 1993). Using tree photoeclectors, DuBOvSKÝ et al. (2010) noted 35 thrips species in the Martinský Les oak forest in 
Slovakia; nine of these species (25\%) were mycophagous. Single specimens of all of them were collected. In High Tatra forest ecosystems 53 thrips species were collected with soil and tree photoeclectors. Only six species (8\%), including $H$. unicolor and $H$. polysticti new to the Slovakian fauna - were fungivorous (MASAROviČ et al. 2014). In SE Finland KETTUNEN (2007) investigated thrips species diversity in pine forests. That author deployed two types of trunk window traps - freely hanging and attached to trunks; most of the saproxylic species were caught in the latter type. Fourteen (26\%) of the 54 thrips species he caught were fungi-feeders, $H$. carpathicus being the most numerous. In Norway KoBRo (2001) collected bark from spruce logs infested by fungi. Using Berlese funnels this author selected six species of fungivorous thrips, among which the brachypterous form of $H$. polysticti was dominant.

In populations of bark-dwelling thrips structural differences between and within sexes are observed, e.g. allometry of the wings, legs and antennae (CRESPI 1986, MOUND 2002). Mound (1976) considers that the presence of apterous or macropterous forms in fungusfeeding thrips is related to the availability of food during larval development. Most of the thrips specimens collected using IBL-2 screen traps in our investigations were macropterous adults, which may suggest that they were caught during their migration to wintering areas or a new food source (KUCHARCZYK \& WYROZUMSKI 2015).

Although using passive traps provides little information on the structure of insect populations and their biology, it does yield fresh data on the biodiversity of the habitats surveyed. Moreover, the minimal impact of IBL-2 traps on the environment and their efficacy - similar to that of other types of passive traps - makes them particularly useful for investigations in protected areas.

\section{REFERENCES}

CRESPI B.J. 1986. Territoriality and fighting in a colonial thrips, Hoplothrips pedicularius, and sexual dimorphism in Thysanoptera. Ecological Entomology 11(2): 119-130.

Dubovský M., Fedor P., Kucharczyk H., Masarovič R., Balkovič J. 2010 Assemblages of barkdwelling thrips (Thysanoptera) of varied in age oak forests in Slovakia. Sylwan 154(10): 659-668. (in Polish)

Gutowski J.M., KRZYSZTOFIAK L. 2005. Directions and intensity of migration of the spruce bark beetle and accompanying species at the border between strict reserves and managed forests in north-eastern Poland. Ecological Questions 6: 81-92.

Jenser G. 1993. Studies on the vertical distribution of some Thysanoptera species in an oak forest. Journal of Pure and Applied Zoology 4: 233-238.

KetTunEN J. 2007. Response of thrips to forest management treatments. [in:] S. TRDAN (ed.). Book of abstracts. Second Symposium on Palearctic Thysanoptera, 8-20 September 2007, Strunjan, Slovenia. University of Ljubljana, Biotechnical Faculty, Department of Agronomy, Ljubljana, 14. 
KoBRo S. 2001. Hoplothrips polysticti (Thysanoptera) on the wood-rotting polypore Trichaptum abietinum infesting dead Picea abies in Norway. Entomologica Fennica 12(1): 15-21.

Kobro S., RAFOSS T. 2006. Identification of adult males and females of Hoplothrips species (Thysanoptera: Tubulifera) known from Norway, an some deduction on their life history. Entomologica Fennica 17(1):184-192.

Kobro S., Solheim H. 2002. Hoplothrips carpathicus PelikÁn, 1961 (Thysanoptera, Phlaeothripidae) in Norway. Norwegian Journal of Entomology 49(2): 143-144.

KUCHARCZYK H. 1994. Thysanoptera of Roztocze. Fragmenta faunistica 37(6): 167-180. (in Polish)

KuChARCZYK H. 1999. Materials for the knowledge of thrips (Thysanoptera) of the Białowieża Forest. Parki Narodowe i Rezerwaty Przyrody 18(Suppl.): 93-100. (in Polish)

KuChARCZYK H. 2004. Thrips (Insecta: Thysanoptera) as an element of ecological monitoring in Białowieża Primeval Forest. Leśne Prace Badawcze 2004, 3: 85-94. (in Polish)

Kucharczyk H. 2007. Thrips (Thysanoptera) [in:] W. Bogdanowicz, E. Chudzicka, I. PiLipiuk, E. SKIBIŃSKA (eds.). Fauna of Poland. Characteristics and checklist of species. Vol. II. Arthropoda pro parte, Insecta pro parte (Coleoptera, Hemiptera, Hymenoptera, Lepidoptera excluduntur), Entognatha. Museum and Institute of Zoology Polish Academy of Sciences, Warsaw, 391-398. (in Polish)

KucharcZyK H., KuCharcZYK M. 2011. Thrips (Thysanoptera) of the beech forests of south-eastern Poland. Leśne Prace Badawcze 72(4): 329-337. (in Polish)

Kucharczyk H., StanisŁaweK K. 2010. Thrips (Thysanoptera) of the mountainous areas in Poland. Wiadomości Entomologiczne, 29(suppl.): 53-64. (in Polish)

Kucharczyk H., Wyrozumski Ł. 2015. Hoplothrips carpathicus Pelikán, 1961 (Thysanoptera: Phlaeothripidae) - a new thrips species in the Polish fauna. Polish Journal of Entomology 84(2): 73-83.

LEwIS T. 1973. Thrips, their biology, ecology and economic importance. Academic Press Inc., London.

MASAROviČ R., FEDOR P., Zvariková M. 2014. Silvicolous thrips (Thysanoptera) in indication of dynamics and disturbance in High Tatras forest ecosystem. Comenius University Publishing, Bratislava. (in Slovak)

Mound L.A. 1976. American leaf-litter Thysanoptera of the genera Erkosothrips, Eurythrips and Terthrothrips (Phlaeothripidae: Phlaeothripinae). Bulletin of the British Museum. Natural History. Entomology 35(2): 27-64.

Mound L.A. 2002. Zemiathrips: a new genus of fungus-feeding phlaeothripine Thysanoptera in Australian leaf-litter. Australian Journal of Entomology 41(3): 209-215.

Mound L.A., KiBBy G. 1998. Thysanoptera: an identification guide. CAB International, Wallingford.

SchliephaKe G., Klimt K. 1979. Die Tierwelt Deutschlands, 66. Thysanoptera, Fransenflügler. Gustav Fischer Verlag, Jena.

Sierka W., Fedor P., Vasiliu-Oromulu L. Jenser G., Bărbuceanu D. 2008. The State of Knowledge of Thrips (Insecta: Thysanoptera) of the Carpathian Mountains. Acta Phytopathologica et Entomologica Hungarica 43(2): 355-366. 
VIERBERGEN G. 2013. Thysanoptera [in:] Fauna Europaea version 2.6.2. Internet: http://www.faunaeur.org. (access 10.07.2015)

ZUR STRASSEN R. 1994. On some rare fungivorous phlaeothripid Thysanoptera (Insecta) from Germany and Sweden. [in:] R. ZUR STRASSEN (ed.). Proceedings of the Workshop on Thysanoptera at Beijing, China, and of the Symposium on Thysanoptera at Halle, Germany, both in 1992. Courier Forschungsinstitut Senckenberg 178: 115-119.

Received: 18 July 2015

Accepted: 18 August 2015 